\title{
PENGARUH KOMPETENSI DAN PROFESIONALISME AUDITOR TERHADAP FRAUD PADA PT. MUSTIKA RATU Tbk
}

\author{
Indra Firmansyah, M. Syafrial Sinaga \\ Program Studi D4 Akuntansi Keuangan, Politeknik Pos Indonesia \\ indrafirmansyah@poltekpos.ac.id, sinagaiyal@gmail.com
}

\begin{abstract}
ABSTRAK
Perusahaan mempunyai suatu tujuan untuk memperoleh keuntungan sebanyak-banyaknya yang dijadikan tuntutan agar perusahaan dapat menjaga kelangsungan hidup perusahaan dan berupaya mengembangkan usahanya. Suatu Penelitian ini bertujuan untuk mengetahui pengaruh kompetensi dan profesionalisme auditor terhadap fraud. Penelitan ini dilakukan pada perusahaan PT.Mustika Ratu Tbk, metode yang digunakan dalam penelitian adalah metode kuantitatif dengan jenis perumusan masalah. Penelitian ini menggunakan data primer berupa kuesioner dan pengambilan sampel dilakukan menggunakan metode nonprobability sampling dengan teknik sampling jenuh. Teknik analisis data yang digunakan dalam penelitian ini adalah Uji Normalitas, Uji Validitas, Uji Reabilitas, Uji Korelasi, Uji Regresi Liner Berganda, Koefisien Determinasi, Uji Hipotesis, Uji T dan Uji F.
\end{abstract}

\section{Kata Kunci: Kompetensi, Profesional Auditor, Fraud}

\section{ABSTRAK}

The company has a goal to get as much profit as possible which is used as a demand so that the company can maintain the company's survival and try to develop its business. This study aims to examine the effect of auditor competence and professionalism on fraud. This research was conducted at the company PT.Mustika Ratu Tbk, the method used in this research is a quantitative method with the type of problem formulation. This study used primary data in the form of a questionnaire and sampling method with a saturated sampling technique. The data analysis techniques used in this research are Normality test, Validity test, Reliability test, Correlation test, Multiple linear Regression test, coefficient of determination, Hypothesis testing, T test and $\mathrm{F}$ test.

Keyword: Competence, Professionalism, Fraud 


\section{PENDAHULUAN}

Semangkin berkembang dan semangkin kompleknya sistem usaha dan pemerintah, tidak memungkinkan bagi eksekutif untuk mengawasi semua kegiatan yang menjdai tanggung jawab. Bagi suatu perusahaan baik kecil atau besar serta BUMN atau Swasta, pengendalian internal tentu sangat dibutuhkan dalam menjaga keberlangsungan opersioanl perusahaan sesuai dengan yang dicita-citakan dan diharapkan oleh perusahaan. Salah satu alat evalusai manajemen tersebut adalah adanya auditor internal perusahaan, auditor internal adalah organisasi dalam perusahaan yang independent, melakukan kegiatan penjaminan (assurance) dan konsultasi (consulting) secara obyektif untuk memberikan nilai tambah dan peningkatan kualitas perusahaan. Internal auditor berfungsi untuk mengendalikan jalannya organisasi, karena internal auditor bertugas mengevalusai kinerja pihak yang di audit guna mengetahui kemungkinan terjadinya penyimpangan,kecurangan tersebut biasanya disebabkan karena lemahnya pengendalian internal didalam perusahaan.

Fenomena seperti yang dilansir dari kontan.co.id (02 Desember 202) terkait fraud yang menerpa PT. Mustika Ratu, kinerja PT. Mustika Ratu Tbk melendai di Sembilan bulan pertama, buktinya, hingga kuartal III-2020, penjualan bersihperusahaan hanya turun $0,04 \%$ menjadi Rp 222,26 miliar. Beradasarkan laporan keunagan perusahaan, penurunan penjualan dipicu oleh penjualan bruto atawa penjualan sebelum dikurangi retur dan potongan penjualan lini produk personal care yang turun $4,22 \%$ secara tahunan atawa yearon-year (YOY) menjadi Rp 196,29 miliar. Sejalan dengan kecurangan yang terjadi di PT. Mustika Ratu cabang Bandung dimana sales mengirimkan barang pemebelian kepada toko, tetapi dari toko tersebut tidak membeli barang tersebut. Sebagaimana skandal fraud di PT. Mustika Ratu cabang Bandung berdampak kepada PT. Mustika Ratu pusat. Hal ini menyebabkan penjualan bersih menurun.

Salah satu tanggung jawab auditor internal adalah pengendalian internal berkaitan tujuan realibilitas pelaporan keuangan. Auditor internal juga melakukan evaluasi desain dan impelementasi pengendalian internal, manajemen resiko, dan governance dalam memastikan pencapai tujuan organisasi. Selain tujuan laporan keuangan, auditor internal juga mengevaluasi efektivitas dan efisiensi serta kepatuhan aktivitas organisasi terhadap ketentuan perundang-undangan dan kontrak, termasuk ketentuan-ketentuan internal organisasi.

Sebagai perusahaan swasta PT. Mustika Ratu cabang Bandung juga memiliki pengendalian internal dan divisi auditor. Pembentukan auditor merupakan wujud pendelegasian wewenang dari direksi, dalam bidang pengawasan. Auditor internal bertanggung jawab untuk memberikan informasi dan rekomendasi kepada manajemen melalui kegiatan pemeriksaan internal. Auditor internal berperan tidak saja membantu manajamen dalam rangka peningkatan pengendalian internal, menajemen resiko (risk management) dan penerapan good corporate governance (GCG).

Auditor internal di PT. Mustika Ratu cabang bandung juga memiliki batasan tanggung jawab yaitu hanya sebatas merencanakan dan melaksanakan auditor sesuai dengan ruang lingkup penugasannya untuk memperoleh keyakinan memadai, bukan atas keyakinan mutlak dan tanggung jawab atas semua permasalahan, baik yang disebabkan oleh keliruan atau kecurangan, obyek auditornya mencakup seluruh kegiatan di PT. Mustika Ratu cabang Bandung.

Berdasarkan laporan auditor tahun 2020 terdapat indikasi yang mengarah pada kecurangan yang terjadi di PT. Mustika Ratu cabang Bandung, dimana terdapat toko tidak memesan pembelian barang dari PT. Mustika Ratu namun sales mengirimkan barang pemeblian kepada toko. Sehingga mengakibatkan terjadinya penurunan laba bersih atau kecurangan pengiriman barang terhadap toko. 
Dengan adanya divisi auditor di PT. Mustika Ratu cabang Bandung ini, diharapkan mampu melaksanakan pengawasan secara optimal sehingga terpenuhnya prinsip-prinsip tata kelolah perusahaan yang baik dan pencapaian tujuan perusahaan yang mencakup seluruh aspek kegiatan perusahaan termasuk anak perusahaanya.

Dari fakta tersebut memberikan gambaran tentang kompetensi dan profesionalisme yang belum berjalan dengan efektif dan effisien. Pengawasan dan kontrol yang belum berjalan dengan baik dan benar akan berakibat sangat besar, kemungkinan terjadinya kesalahan atau kecurangan dalam perusahaan.

Merujuk pencegahaan kecurangan yang perna dilakukan oleh Nuri Fitmartsari (2018) pada 11 KAP kota Bandung. Dalam hipotesisi pertamanya beliau memperoleh hasil penelitian yang menunjukan adanya pengaruh antar kompetensi berpengaruh terhadap pencegahan fraud. Hal ini menunjukan bahwa auditor internal secara persial berpengaruh terhadap pencegahan fraud.

Hipotesis kedua menyatakan bahwa efektivitas profesionalisme auditor berpengaruh terhadap pencegahan fraud. Hal ini menunjukan bahwa pengetahuan auditor berpengaruh signifikan terhadap pendeteksian temuan kerugian daerah.

Hipotesis ketiga menyatakan bahwa kompetensi dan profesionalisme auditor berpengaruh terhadap pencegahan fraud, kompetensi dan profesionalisme auditor bertujuan untuk pencegahan kecurangan. Secara bersama-sama diketahui bahwa variabel yang dominan mempengaruhi pencegahan fraud adalah variabel auditor internal.

Sesuai dengan latar belakang diatas maka yang menjadi identifikasi masalah pada penelitian tersebut adalah sebagai berikut:

1. Bagaiman pengaruh kompetensi terhadap fraud di perusahaan PT.Mustika Ratu Tbk.

2. Bagaiman pengaruh profesionalisme auditor terhadap fraud di perusahaan PT. Mustika Ratu Tbk.

3. Bagaimana pengaruh kompetensi dan profesionalisme auditor terhadap fraud di perusahaan PT. Mustika Ratu Tbk.

\section{KAJIAN PUSTAKA \\ Pengertian Audit}

Auditing menurut (Agoes, 2017) adalah: "Suatu pemeriksaan yang dilakukan secara kritis dan sistematis, oleh pihak yang independent, terhadap laporan keuangan yang telah disusun oleh manajemen, beserta catatan-catatan pembukuan dan bukti-bukti pendukungnya, dengan tujuan untuk dapat memberikan pendapatan mengenai kewajaran laporan keuangan tersebut".

Menurut (Mulyadi, 2016) audit adalah Proses sistematik untuk memperoleh dan mengevaluasi bukti secara objektiv mengenai pernyataan-pernyataan tentang kegiatan ekonomi, dengan tujuan untuk menetapkan tingkat kesesuaian antara pernyataanpernyataan tersebut dengan kriteria yang telah ditetapkan, serta penyampaian hasilhasilnya kepada pemakai yang berkepentingan, ditinjau dari sudut profesi akuntan publik, audit adalah pemeriksaan secara objektif atas laporan keuangan suatau perusahaan atau organisasi lain dengan tujuan untuk menentukan apakah laporan keuangan tersebut menyajikan secara wajar, dalam semua hal yang material. Posisi keuangan, dan hasil usaha perusahaan atau organisasi tersebut.

\section{Jenis -Jenis Audit}

Ditinjau dari luasnya pemeriksaan, audit menurut (Agoes, 2017) bisa dibedakan atas:

1. Pemeriksaan Umum (General Umum)

Suatu Pemeriksaan umum atas laporan keuangan yang dilakukan oleh KAP independen dengan tujuan untuk bisa memberikan pendapat mengenai kewajaran laporan keuangan secara keseluruhan. Pemeriksaan harus dilakukan sesuai dengan Standar 
Profesional Akuntan Publik atau ISA atau Panduan Audit Entitas Bisnis Kecil dan memperhatikan Kode Etik Akuntan Indonesia, Kode Etik Profesi Akuntan Publik serta Standar Pengendalian Mutu.

2. Pemeriksaan Khusus (Special Audit)

Suatu pemeriksaan terbatas (sesuai dengan permintaan auditee) yang dilakukan oleh KAP yang independen, dan pada akhir pemeriksaannya auditor tidak perlu memberikan pendapat terhadap kewajaran laporan keuangan secara keseluruhan. Pendapat yang diberikan terbatas pada pos atau masalah tertentu yang bisa diperiksa, karena prosedur audit yang dilakukan juga terbatas. Misalnya KAP diminta untuk memeriksa apakah terdapat kecurangan terhadap penagihan piutang usaha di perusahaan. Dalam hal ini prosedur audit terbatas untuk memeriksa piutang usaha, penjualan, dan penerimaan kas.

\section{Tujuan Audit Internal (Internal Auditor)}

Berbeda dengan pemeriksaan yang dilakukan oleh KAP (Kantor Akuntan Publik), yang tujuannya adalah memberikan pendapat atas kewajaran laporan keuangan yang disusun manajemen, maka tujuan pemeriksaan yang dilakukan oleh internal auditor adalah untuk membantu semua pimpinan perusahaan (manajemen) dalam melaksanakan tanggung jawabnya dengan memberikan analisis, penilaian, saran dan komentar terkait kegiatan yang menjadi objek pemeriksaannya.

\section{Pengertian Kompetensi Audit Internal}

Menurut (Rai, 2010) kompetensi adalah kemampuan individu untuk melaksankan suatu pekerjaan denagan benar dan memiliki keunggulan yang didasarkan pada hal-hal yang menyangkut pengetahuan, keahlian dan sikap. Menurut parah ahli, adalah sebagai berikut:

1. Menurut (Rai, 2010) karakteristik yang mendasari individu yang berkaitan dengan hubungan kausal atau sebab-akibat pelaksanaan yang efektif dan unggul dalam pekerjaan atau keadaan.

\section{Manfaat Kompetensi}

Manfaat Kompetensi menurut (Rai, 2010) kompetensi begitu penting dalam dunia usaha sebagai dasar prekrutan (recruitmen). Bahkan beberapa pakar menyatakan IQ tinggi belum tentu menjamin keberhasilan karna hasil IQ lebih banyak kearah "kecendrungan" menurut Daniel Golem, "kecendrungan" IQ (Intelligence Quotience) bukan segala-galanya dalam meraih kesuksesan.

\section{Indikator Kompetensi}

Indikator kompetensi menurut (Rai, 2010) untuk memunuhi unsur kompetensi, seseorang pegawai harus memenuhi unsur-unsur dibawah ini.

1. Pengetahuan

2. Keahlian

3. Sikap

\section{Pengertian Profesionalisme Audit Internal}

Menurut (Agoes, 2017) profesionalisme adalah mutu, kualitas dan tidak tanduk yang merupakan ciri suatu profesi atau orang yang profesional. Dalam pelaksanaan pemeriksaan dan penyusunan laporan audit, pemeriksa wajib menggunakan kemahiran profesionalnya dengan cermat dan seksama yang tercantum dalam standar umum yang pertama dalam Standar Profesional Akuntansi Publik (SPAP).

\section{Pengukuran Profesionalisme Auditor Internal}

Menurut (Agoes, 2017) terdapat lima dimensi profesionalisme,yaitu:

1. Pengabdian pada profesi

2. Kewajiaban social

3. Kemendirian

4. Keyakinan terhadap peraturan profesi 
5. Hubungan dengan sesama profesi

\section{Pengertian (fraud)}

Dalam Kamus Besar Bahasa Indonesia, curang adalah tidak jujur, tidak lurus hati, tidak adil maupun menipu. kecurangan adalah perihal curang, perbuatan yang curang, ketidakjujuran, dan keculasan.

Menurut (Arum Ardianingsih, 2018) pengertian kecurangan adalah "Fraud is an intentional act involving the use of deception that results in a material misstatement of the financial statements". Pernyataan tersebut menjelaskan bahwa kecurangan adalah sebuah tindakan disengaja yang melibatkan pelaku penipuan yang menghasilkan bahan salah saji laporan keuangan.

\section{Bentuk-bentuk Fraud}

(Arum Ardianingsih, 2018) mengklasifikasikan bahwa fraud bisa terjadi dalam berbagai bentuk sebagai berikut.

1. International misrepresentation: memberi saran bahwa sesuatu itu benar, padahal itu salah, oleh seseorang yang mengetahui bahwa itu salah.

2. Negligent misrepresentation: pernyataan bahwa sesuatu itu salah oleh seseorang yang tidak mempunyai dasar yang kuat untuk menyatakan bahwa itu betul.

3. Mengetahui kepada pihak lain, sesuatu yang seharusnya dirahasiakan. Misalnya memberikan inside information di pasar modal.

4. False promise: suatu janji yang diberikan tanpa keinginan untuk memenuhi janji tersebut.

5. Employee fraud: kecurangan yang dilakukan seorang pegawai untuk menguntungkan dirinya sendiri. Hal ini banyak kita jumpai dalam kehidupan sehari-hari, mulai dari office boy yang "memainkan" bon pembelian makanan sampai pegawai yang memasukkan biaya entertainment untuk keluarga sebagai biaya perusahaan.

6. Management fraud: kecurangan yang dilakukan oleh manajemen sehingga merugikan pihak lain, termasuk pemerintah. Misalnya manipulasi pajak, manipulasi kredit bank, kontraktor yang menggunakan "cost plus fee".

7. Organized crime: kecurangan yang terorganisir, misalnya pemalsuan kartu kredit, pengiriman barang melebihi atau kurang dari yang seharusnya di mana si pelaksana akan mendapat bagian $10 \%$.

8. Computer crime: dengan memanfaatkan teknologi komputer, sehingga sipelaku bisa mentransfer dana dari rekening orang lain ke rekeningnya sendiri (pernah dilakukan WNI di Amerika).

9. White collar crime: kejahatan yang dilakukan orang-orang berdasi (kalangan atas), misalnya mafia tanah, paksaan secara halus untuk merger dan lain-lain.

\section{METODOLOGI PENELITIAN}

\section{Jenis Penelitian}

Metode penelitian kuantitatif menurut (Sugiyono, 2017)adalah "Dapat diartikan sebagai metode penelitian yang berlandaskan pada filsafat positivisme, digunakan untuk meneliti pada populasi atau sampel tertentu, pengumpulan data mengunakan instrument penelitian, analisis data bersifat kuantitatif/statistik, dengan tujuan untuk menguji hipotesis yang telah ditetapkan". Analisis data yang digunakan adalah uji validitas, uji realianilitas, uji normalitas data, analisis korelasi spearman rank, uji korelasi berganda, analisis regresi berganda, koefisien determinasi, uji t dan uji f.

\section{Operasionalisasi Variabel}

(Sugiyono, 2017) mendefinisikan "variabel penelitian adalah suatu atribut atau sifat atau nilai dari orang, obyek, atau kegiatan yang mempunyai variasi tertentu yang ditetapkan 
oleh peneliti untuk dipelajari dan kemudian ditarik kesimpulannya". Untuk penelitian ini operasionalisasi variabel disajikan dalam bentuk tabel, dimana terdiri dari variabel yang terkait, definisi yang diambil sebagai landasan, indikator, skala ukur yang digunakan, nomor kuisioner, serta alat analisis yang akan digunakan dalam pengolahan hasil penelitian.

\section{Teknik Pengumpulan Data}

Menurut Sugiyono (2017:308) adalah cara atau teknik pengumpulan data merupakan langkah yang paling utama dalam penelitian, karena tujuan utama dari penelitian adalah mendapatkan data. Dimana teknik pengumpulan data, maka peneliti tidak akan mendapatkan data yang memenuhi standar data yang ditetapkan. Pengumpulan data dapat dilakukan dalam berbagai setting, berbagai sumber, dan berbagai cara.

\section{Teknik Sampling}

Beradasarkan pernyataan (Sugiyono 2017.81) Teknik sampling adalah merupakan teknik pegambilan sampel. Untuk mengetahui sampel yang akan digunakan dalam penelitian, terdapat berbagai jenis Teknik sampling yang digunakan. Dalam sebuah penelitian Teknik sampling umumnya dibagi menjadi 2 yang dijelskan sebagai berikut ini:

1. Probability Sampling

2. NonProbability Sampling

\section{Populasi}

Menurut Sugiyono (2017:215) adalah “ keseluruhan dari obyek atau subyek yang mempunyai kualitas dari karakteristik tertentu yang ditetapkan oleh peneliti untuk dipelajari dan kemudian ditarik kesimpulannya".

Obyek yang akan diteliti dalam populasi disebut dengan unit analisis atau elemen populasi. analisis ini dapat berupa orang, perusahaan, media dan sebagainya.

\section{Sampel}

Menurut Sugiyono (2017:215) pengertian sampel adalah "Bagian dari jumlah dan karaktertistik yang dimiliki oleh populasi tersebut".

\begin{tabular}{|c|c|c|c|}
\hline Nama & $\begin{array}{c}\text { Jumlah } \\
\text { Pegawai }\end{array}$ & Total & Peresentase (\%) \\
\hline $\begin{array}{c}\text { Audit } \\
\text { Internal }\end{array}$ & 8 & 8 & $40 \%$ \\
\hline BPI & 12 & 12 & $60 \%$ \\
\hline Jumlah & 20 & 20 & $100 \%$ \\
\hline
\end{tabular}

menurut tabel diatas penelitian ini teknik sampling yang digunakan yaitu NonProbability Sampling. Non Propability sampling yang digunakan dalam penelitian ini adalah sampling jenuh dimana Teknik penentuan sampel bila semua anggota populasi digunakan sebagai sampel. Hal ini sering dilakukan bila jumlah populasi relative kecil, maka sampel dalam penelitian ini adalah sebanyak 20 responden dimana semua anggota populasi dijadikan sampel.

\section{Teknik Analisis Data}

Dalam penelitian ini teknik analisis yang digunakan peneliti adalah teknik analisis kuantitatif. Menurut (Sugiyono, 2017)Teknik analisis data yang digunakan sudah jelas, yaitu diarahkan untuk menjawab rumusan masalah atau menguji hipotesis.

\section{HASIL PENELITIAN DAN PEMBAHASAN Uji Validitas}

Dalam penelitian ini, pengujian validitas berupa kuesioner yang terdiri atas 9 pernyataan dengan pembagian 3 pertanyaan untuk kompetensi pada PT.Mustika Ratu Tbk $\left(\mathrm{X}_{1}\right), 3$ pertanyaan untuk profesionalisme auditor dan pertanyaan untuk fraud pada 
PT.Mustika Ratu Tbk (Y). Pada penelitian ini sampel berjumlah 20 responden. Sehingga diperoleh rtabel.

Tabel Validitas Kompetensi di PT.Mustika Ratu Tbk

\begin{tabular}{|c|c|c|c|}
\hline Pertanyaan & $\begin{array}{c}\text { Corrected Item- } \\
\text { Total Correlation }\end{array}$ & Rtabel & Keterangan \\
\hline P1 & 0,900 & 0,444 & VALID \\
\hline P2 & 0,900 & 0,444 & VALID \\
\hline P3 & 0.839 & 0,444 & VALID \\
\hline
\end{tabular}

Sumber:Data Kuesioner diolah

Tabel Validitas Profesionalisme Auditor di PT.Mustika Ratu Tbk

\begin{tabular}{|c|c|c|c|}
\hline Pertanyaan & $\begin{array}{c}\text { Corrected Item- } \\
\text { Total Correlation }\end{array}$ & Rtabel & Keterangan \\
\hline P4 & 0,953 & 0,444 & VALID \\
\hline P5 & 0,922 & 0,444 & VALID \\
\hline P6 & 0.943 & 0,444 & VALID \\
\hline
\end{tabular}

Sumber: Data kuesioner diolah

Tabel Validitas Fraud di PT.Mustika Ratu Tbk

\begin{tabular}{|c|c|c|c|}
\hline Pertanyaan & $\begin{array}{c}\text { Corrected Item- } \\
\text { Total Correlation }\end{array}$ & Rtabel & Keterangan \\
\hline P7 & 0,880 & 0,444 & VALID \\
\hline P8 & 0,757 & 0,444 & VALID \\
\hline P9 & 0.714 & 0,444 & VALID \\
\hline
\end{tabular}

Sumber: Data kuesioner diolah

Berdasarkan tabel hasil uji validitas di atas, seluruh item pernyataan pada variable $\mathrm{X}_{1}$, $\mathrm{X}_{2}$, dan $\mathrm{Y}$ dinyatakan valid kerena hasil rhitung lebih besar dari pada rtabel $(0,444)$. Sehingga dapat disimpulkan bahwa sebanyak 9 pernyataan dalam kuesioner ini telah valid dan dapat digunakan dalam penelitian.

Uji Reabilitas

Tabel

Hasil Uji Realiabilita Kompetensi $\left(\mathrm{X}_{1}\right)$, Profesionalisme Auditor $\left(\mathrm{X}_{2}\right)$ dan $\operatorname{Fraud}(\mathrm{Y})$

\begin{tabular}{|l|c|c|c|}
\hline \multicolumn{1}{|c|}{ Variabel } & $\begin{array}{c}\text { Cronbach's } \\
\text { Alpha }\end{array}$ & $\begin{array}{c}\text { Standarized } \\
\text { Alpha }\end{array}$ & Keterangan \\
\hline Kompetensi $\left(\mathrm{X}_{1}\right)$ & 0,856 & 0,60 & Reliabel \\
\hline $\begin{array}{l}\text { Profesionalisme } \\
\text { Auditor }\left(\mathrm{X}_{2}\right)\end{array}$ & 0.874 & 0,60 & Reliabel \\
\hline Fraud $(\mathrm{Y})$ & 0,817 & 0,60 & Reliabel \\
\hline
\end{tabular}

Sumber: Pengolahan data SPSS

Berdasarkan tabel terlihat bahwa nilai Cronbach's Alpha Kompetensi sebesar 0,856, nilai Cronbach's Alpha Profesional Auditor sebesar 0,874 dan Cronbach's Alpha fraud sebesar 0,817. Hal ini menunjukan bahwa, nilai ini telah melewati syarat ralibilitas sebesar 0.60. Maka dapat dikatakan bahwa Kompetensi, Profesional Auditor dan Fraud adalah reliabel.

\section{Uji Normalitas}

Berdasarkan hasil analisis uji normalitas yang dilihat pada tabel 4.11 dan mengacu pada kolom Kolmogorov-Smirnova menunnjukan bahwa Variable $\mathrm{Y}$ fraud, Variabel $\mathrm{X}_{1}$ Kompetensi, Variabel $\mathrm{X}_{2}$ Profesionalisme Auditor memiliki nilai Sig. sebesar 0,095. Dimana angka tersebut menunjukan $0,95 \geq 0,05$ maka dari hasil data tersebut dapat disimpulkan berdistribusi normal.

Uji Korelasi Spearman Rank 
Karena berdasarkan hasil analisis korelasi yang menunjukkan angka 0,735. Maka dapat dilihat pada tabel bahwa $\mathrm{r}$ berada diantara $0,40-0,599$ artinya memiliki hubungan yang kuat. Dengan demikian dapat dikatakan Kompetensi $\left(\mathrm{X}_{1}\right)$ memiliki hubungan yang kuat terhadap Fraud (Y). Berdasarkan hasil analisis korelasi yang menunjukkan angka 0,814. Maka dapat dilihat pada tabel bahwa $\mathrm{r}$ berada diantara $0,80-1,000$ artinya memiliki tingkat hubungan yang sangat kuat. Dengan demikian dapat dikatakn Profesional Auditor $\left(\mathrm{X}_{2}\right)$ memiliki tingkat hubugan yang sangat kuat terhadap Fraud (Y).

\section{Regresi Linier Berganda}

Berdasarkan hasil analisis regresi berganda yang dilihat pada tabel 4.14 hasil pengelolahan data menggunakan SPSS 24.00, maka didapatkan persamaan sebagai berikut:

$\mathrm{Y}=\mathrm{a}+\mathrm{b} 1 \mathrm{x} 1+\mathrm{b} 2 \times 2$

$\mathrm{Y}=1,857+0,420 \mathrm{X}_{1}+0,450 \mathrm{X}_{2}$

Diminta :

$\mathrm{Y} \quad=$ Fraud

a $\quad=$ Konstanta

b1b2 = Kofesien Regresi

$\mathrm{X}_{1} \quad=$ Kompetensi

$\mathrm{X}_{2} \quad=$ Profesional Auditor

Dari persamaan tersebut, dapat diartikan sebagai berikut:

1. Konstanta (a)

Jika variabel Kompetensi $\left(\mathrm{X}_{1}\right)$ dan Profesional Auditor $\left(\mathrm{X}_{2}\right)$ nilainya 0, maka nilai variabel Fraud (Y) adalah sebesar 1.857.

2. Kompetensi $\left(\mathrm{X}_{1}\right)$ terhadap Fraud $(\mathrm{Y})$

Koefisien regresi variabel Kompetensi $\left(\mathrm{X}_{1}\right)$ sebesar 0,420 artinya jika variabel Kompetensi $\left(\mathrm{X}_{1}\right)$ mengalami kenaikan 1, maka Fraud $(\mathrm{Y})$ akan mengalami penurunan 0,420 , karena koefisien bernilai positif maka terjadi hubungan positif pula antara Kompetensi $\left(\mathrm{X}_{1}\right)$ terhadap Fraud $(\mathrm{Y})$. Jadi, kenaikan Kompetensi $\left(\mathrm{X}_{1}\right)$ mengakibatkan peningkatan pada Fraud (Y).

3. Profesional Auditor $\left(\mathrm{X}_{2}\right)$ terhadap Fraud $(\mathrm{Y})$

Koefisien regresi variabel Profesional Auditor $\left(\mathrm{X}_{2}\right)$ sebesar 0,450 artinya jika variabel Profesional Audtor $\left(\mathrm{X}_{2}\right)$ mengalami kenaikan 1, maka Fraud $(\mathrm{Y})$ akan mengalami peningkatan sebesar 0,450. Karena koefisien bernilai positif maka terjadi hubungan positif pula antara Profesional Auditor $\left(\mathrm{X}_{2}\right)$ terhadap Fraud (Y). Jadi, kenaikan Profesional Auditor $\left(\mathrm{X}_{2}\right)$ mengakibatkan peningkatan pada Fraud $(\mathrm{Y})$.

\section{Uji Korelasi Berganda}

Uji korelas berganda digunakan untuk mengetahui tingkat keeratan hubungan simultan antara dua atau lebih variabel bebas $(\mathrm{X})$ terhadap terikat $(\mathrm{Y})$.

Berdasarkan hasil analisis korelasi berganda yang dilihat pada tabel 4.16 di atas, maka didapatkan angka R sebesar 0,921. Berdasarkah hasil uji tersebut dapat dijelaskan merujuk pada tabel kategori koefisien korelasi yang mana masuk pada interval korelasi $(0,80-$ 1,000) maka disimpulkan tingkat hubungan korelasi berganda dari Kompetensi dan Profesionalisme Auditor terhadap Fraud mempunyai tingkat hubungan yang sangat kuat.

\section{Uji Hipotesis Statistik $\mathbf{t}$ (Parsial)}

Berdasarkan hasil analisis uji hipotesis statistic $\mathrm{t}$ (Parsial) yang dilihat pada tabel 4.17 diatas, yang didasari dari teori harga t hitung selanjutnya dibandingkan dengan $t$ tabel dan tingkat signifikansi 5\% maka dapat dijelaskan sebagai berikut:

1. Melakukan hipotesis pengujian Kompetensi $\left(\mathrm{X}_{1}\right)$ terhadap $\operatorname{Fraud}(\mathrm{Y})$.

Berdasarkan hasil analisis pengujian Kompetensi terhadap Fraud maka didapatkan angka sebesar $t_{\text {hitung }}=3,844$ karena menggunakan uji 2 pihak, dengan dk atau derajat 
kebebasan sebesar 17 yang didapat dari $(\mathrm{df})=\mathrm{n}-\mathrm{k}-1$ atau $(20-2-1)$ dan didapat $\mathrm{t}_{\text {tabel }}$ sebesar 2,110 . Maka analisis uji $t$ tersebut dapat dituliskan $t_{\text {hitung }}(3.844)>t_{\text {tabel }}(2,110)$, yang mana dapat ditarik kesimpulan Ha diterima dan Ho ditolak yang artinya terdapat pengaruh yang signifikan antara Kompetensi terhadap Fraud di PT.Mustika Ratu Tbk.

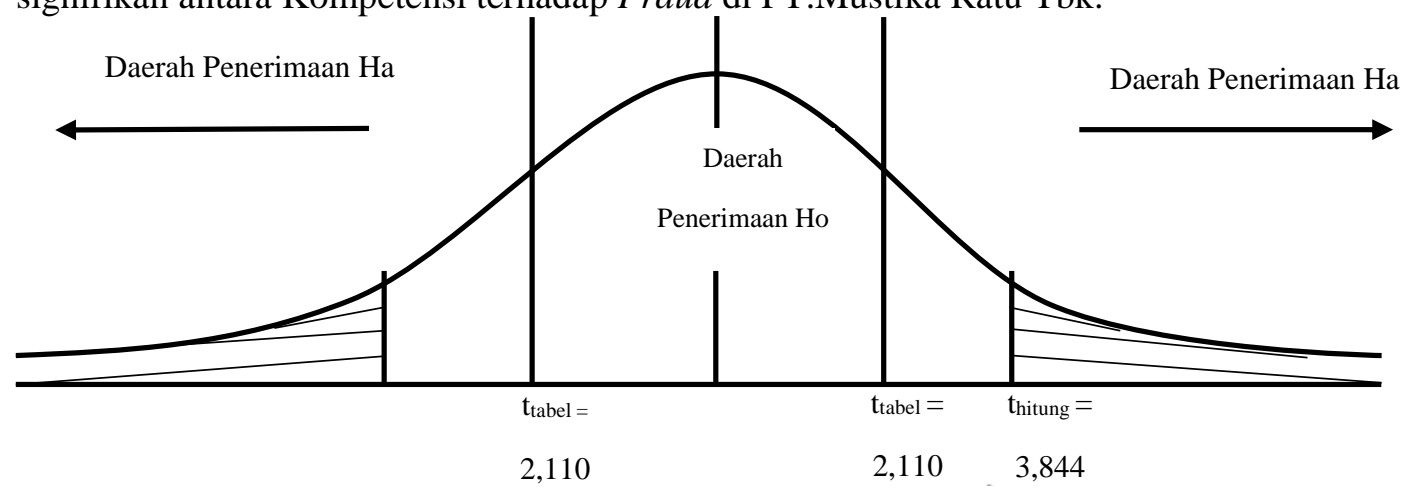

Kurva Distribusi X1 terhadap Y

2. Melakukan hipotesis pengujian Profesional Auditor $\left(\mathrm{X}_{2}\right)$ terhadap Fraud $(\mathrm{Y})$.

Berdasarkan hasil analisis pengujian Profesional Auditor terhadap Fraud maka didapatkan angka sebesar $t_{\text {hitung }}=(5,350)$, karena menggunakan uji 2 pihak, dengan dk atau derajat kebebasan sebesar 17 yang didapat dari $(\mathrm{df})=\mathrm{n}-\mathrm{k}-1$ atau $(20-2-1)$ dan didapat $t_{\text {tabel }}$ sebesar 2,110. Maka analisis uji $t$ tersebut dapat ditulisakan $t_{\text {hitung }}(5,350)>t_{\text {tabel }}(2,583)$. Yang mana dapat ditarik kesimpulan Ha diterima dan Ho ditolak yang artinya terdapat pengaruh yang signifikan antara Profesional Auditor terhadap Fraud di PT.Mustika Ratu Tbk.

Maka dapat digambarkan kurva sebagai berikut:

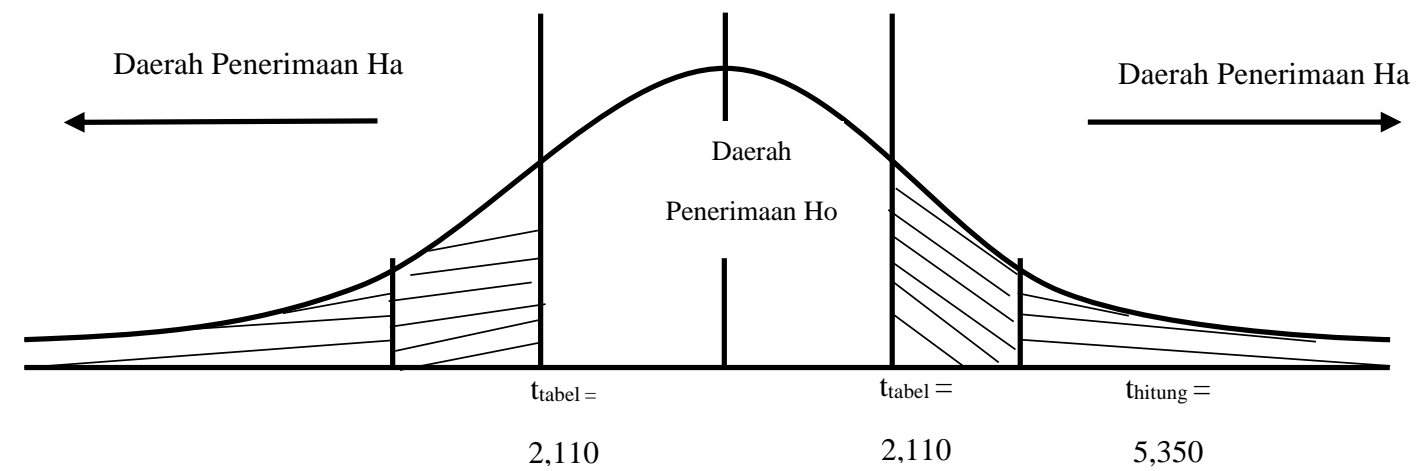

Distribusi Kurva X2 terhadap Y

\section{Uji Hipotesis Statistik F (Simultan)}

Berdasarkan hasil analisis uji hipotesis $\mathrm{f}$ (simultan) yang dilihat pada tabel dapat diketahui nilai $t_{\text {hitung }}$ serta pengaruh signifikan dengan mengetahui nilai koefisiensi anova. Berikut ini hipotesis yang telah dirumuskan dalam penelitian. 


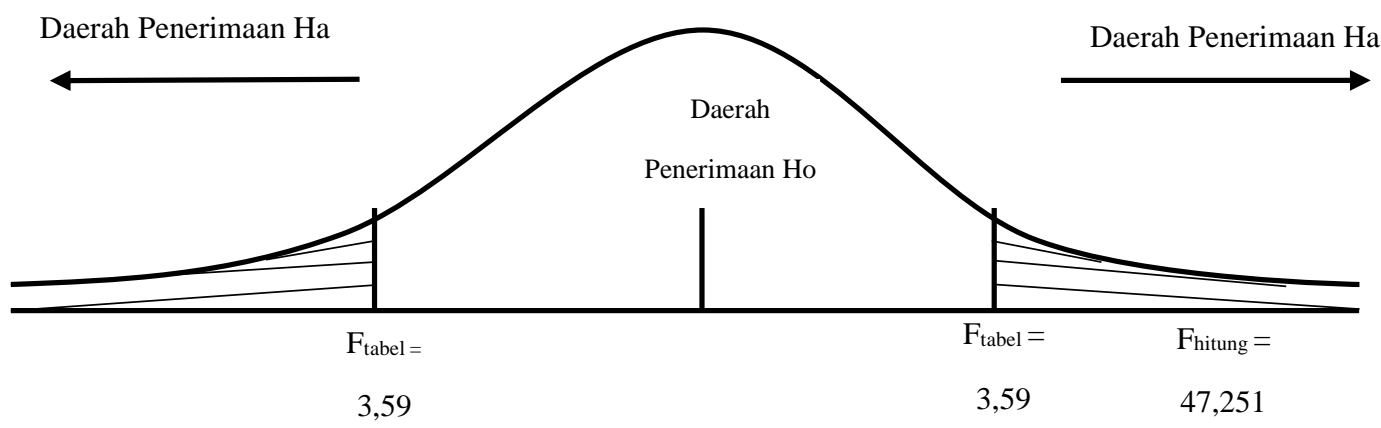

Dari hasil output uji diatas kompetensi dan professional auditor adalah 47,251 dengan nilai signifikan 0,000. Maka dari itu diketahui hasil ftabel ( $\left.f_{\text {hitung }} \geq f_{\text {tabel }}\right)$, yaitu 47,251 > 3,59, maka demikian Ha diterima dan Ho ditolak.

\section{Analisis Koefisien Determinasi}

Berdasarkan hasil analisis koefisien determinasi, menunjukan bahwa nilai dari koefisiensi determinasi memiliki 0,921.

Berikut perhitungan secara manual untuk mendapatkan $\mathrm{R}$ square:

$\mathrm{KD}=\mathrm{r}^{2} \times 100 \%$

$\mathrm{KD}=0,921^{2} \mathrm{X} 100 \%$

$\mathrm{KD}=84,8 \%$

Dari tabel diatas dapat diketahui nilai $\mathrm{R}$ square atau koefisien determinasi adalah $84,8 \%$, maka nilai tersebut mempunyai arti bahwa sebesar $84,8 \%$ variasi dari variabel Fraud dapat dipengaruhi oleh Kompetensi $\left(\mathrm{X}_{1}\right)$ dan Profesionalisme Auditor $\left(\mathrm{X}_{2}\right)$. Sedangkan sisanya yaitu $15,2 \%$ dari variabel Fraud dipengaruhi oleh variabel lainnya (faktor lain) yang tidak dimasukan dalam penelitian.

\section{Pembahasan}

Pada penelitian ini menjelaskan tentang hasil penelitian yang dilakukan oleh peneliti dengan menggunakan data primer yang menggunkan kuesioner yang disebar di PT.Mustika Ratu Tbk, berikut pembahasan hasil penelitian yang telah dilakukan oleh peneliti yaitu sebagai berikut.

\section{Pengaruh Kompetensi dan Profesional Auditor terhadap Fraud di PT. Mustika Ratu} Tbk.

Penelitian ini menggunakan sumber data yang didapatkan dari data primer dari PT.Mustika Ratu Tbk. Berikut pembahasan hasi penelitian kompetensi terhadap fraud sebagai berikut:

1. Berdasarkan hasi uji normalitas yang dilakukan dengan mengacu pada kolom Kolmogorov - Smirnova menunjukan bahwa variabel kompetensi pemerintah terhadap fraud memiliki nilai Sig. Sebesar 0,799. Dimana hal tersebut menunjukan 0,799 >0,05 maka dengan demikian data tersebut dinyatakan berdistribusi noramal.

2. Berdasarkan hasil analisis uji korelasi spearman rank didapatkan angka sebesar 0,735. Berdasarkan hasil analisis korelasi yang menunjukan angka 0,735. Maka dapat dilihat pada tabel bahwa $r$ berada diantara 0,49 - 599 artinya memiliki hubungan sedang. Dengan demikian dapat dikatakan kompetensi $\left(\mathrm{X}_{1}\right)$ memiliki hubungan yang sedang Fraud $(\mathrm{Y})$.

3. Berdasarkan hasil uji analisi regresi berganda yang dilakukan dengan mengahsilkan sebuah persamaan $\mathrm{Y}=1,857+0,420 \mathrm{X}_{1}+0,450 \mathrm{X}_{2}$ yang menjelaskan bahwa jika variabel kompetensi $\left(\mathrm{X}_{1}\right)$ mengalami kenaikan 1, maka Fraud $(\mathrm{Y})$ akan mengalami penurunan sebesar 0,420. Karena kofesien bernili positif maka terjadi hubungan positif pula antara Kompetensi $\left(\mathrm{X}_{1}\right)$ terhadap Fraud $(\mathrm{Y})$. 
4. Berdasarkan hasil uji hiptesis statistic $\mathrm{t}$ didapatkan angka sebesar $\mathrm{t}_{\text {hitung }} 3,844>2,110$, dikarenakan nilai $t_{\text {hitung }}>t_{\text {tabel }}$ dan angka signifikan sebesar $0,001<0,05$ yang mana dapat ditarik kesimpullan bahwa Ha diterima dan Ho ditolak yang artinya terdapat pengaruh yang signifikan antara Kompetensi terhadap Fraud di PT.Mustika Ratu Tbk.

Hasil penelitian ini menghasilkan kesimpulan yang berada dengan penelitian sebelumnya yang dilakukan oleh (Nugrahini, 2015) dimana penelitiannya berkesimpulan Kompetensi berpengaruh signifikan terhadap Fraud.

\section{Pengaruh Profesionalisme Auditor terhadap Faud di PT. Musika Ratu Tbk.}

Penelitian ini menggunkan sumber data yang didapat dari data primer dari PT. Mustika Ratu Tbk. Berikut pembahasan hasil penelitian Profesionalisme Auditor terhadap Fraud sebagai berikut:

1. Berdasarkan hasil uji normalitas yang dilakukan dengan mengacu pada kolom Kolmogorov - Smirnova menunjukan bahwa variabel profesional auditor memiliki nilai 0,95>0,05 maka dengan demikian data tersebut dinyatakan berdistribusi normal.

2. Berdasarkan hasil analisis uji korelasi spearman rank didapatkan angka sebesar 0,814 maka dapat dilihat pada table bahwa $r$ berada diantara 0,80 - 1,000 artinya memiliki tingkat hubungan yang sangat kuat. Dengan demikian dapat dikatakan Profesional Auditor $\left(\mathrm{X}_{2}\right)$ memiliki tingkat hubungan yang sangat kuat $\operatorname{Fraud}(\mathrm{Y})$.

3. Berdasarkan hasil uji analisi regresi berganda yang dilakukan dengan mengahsilkan sebuah persamaan $Y=1,857+0,420 X_{1}+0,450 X_{2}$ yang menjelaskan bahwa jika variabel Profesional Auditor $\left(\mathrm{X}_{2}\right)$ mengalami kenaikan 1, maka Fraud (Y) akan mengalami penurunan sebesar 0,450. Karena kofesien bernili positif maka terjadi hubungan positif pula antara Profesional Auditor $\left(\mathrm{X}_{2}\right)$ terhadap $\operatorname{Fraud}(\mathrm{Y})$.

4. Berdasarkan hasil uji hiptesis statistic $t$ didapatkan angka sebesar $t_{\text {hitung }} 5,350>$ 2,110 , dikarenakan nilai $t_{\text {hitung }}>\mathrm{t}_{\text {tabel }}$ dan angka signifikan sebesar $0,000<0,05$ yang mana dapat ditarik kesimpullan bahwa Ha diterima dan Ho ditolak yang artinya terdapat pengaruh yang signifikan antara Profesional Auditor terhadap Fraud di PT.Mustika Ratu Tbk.

Hasil penelitian ini menghasilkan kesimpulan yang berada dengan penelitian sebelumnya yang dilakukan oleh (Nugrahini, 2015) dimana penelitiannya berkesimpulan Kompetensi berpengaruh signifikan terhadap Fraud.

Pengaruh Kompetensi dan Profesional Auditor terhadap Fraud di PT. Mustika Ratu Tbk.

Penelitian ini menggunakan sumber data yang didapat dari data primer dari PT. Mustika Ratu Tbk. Berikut pembahasan hasil penelitin kompetensi dan profesional auditor terhadap fraud sebagai berikut:

1. Berdasarkan hasi uji normalitas yang dilakukan dengan mengacu pada kolom Kolmogorov - Smirnova menunjukan bahwa variabel kompetensi pemerintah terhadap fraud memiliki nilai Sig. Sebesar0,799. Dimana hal tersebut menunjukan 0,799>0,05 maka dengan demikian data tersebut dinyatakan berdistribusi noramal dan variabel profesional auditor memiliki nilai 0,95>0,05 maka dengan demikian data tersebut dinyatakan berdistribusi normal.

2. Berdasarkan hasil analisis uji korelasi spearman rank didapatkan angka sebesar 0,735. Berdasarkan hasil analisis korelasi yang menunjukan angka 0,735. Maka dapat dilihat pada tabel bahwa $\mathrm{r}$ berada diantara 0,49 - 599 artinya memiliki hubungan sedang. Dengan demikian dapat dikatakan kompetensi $\left(\mathrm{X}_{1}\right)$ memiliki hubungan yang sedang Fraud $(\mathrm{Y})$, jika variabel Profesional Auditor $\left(\mathrm{X}_{2}\right)$ mengalami kenaikan 1, maka Fraud 
(Y) akan mengalami penurunan sebesar 0,450. Karena kofesien bernili positif maka terjadi hubungan positif pula antara Profesional Auditor $\left(\mathrm{X}_{2}\right)$ terhadap Fraud $(\mathrm{Y})$.

3. Berdasarkan hasil uji koefisien determinasi yang dilakukan dengan mengacu pada kolom model summary didapatkan angka sebesar 8,48 variasi dari variabel fraud dapat dipengaruhi oleh Kompetensi $\left(\mathrm{X}_{1}\right)$ dan Profesional Auditor $\left(\mathrm{X}_{2}\right)$. Sedangkan sisanya yaitu 0,9152 atau 91,52 dari variabel Fraud dipengaruhi oleh variabel lainnya (faktor lain) yang tidak dimasukan dalam peneliti ini.

4. Berdasarkan hasil analisis uji korelasi berganda dapat dijelaskan merujuk pada tabel kategori koefisien korelasi yang mana masuk pada interval korelasi $(0,80-1,000)$ maka disimpulkan tingkat hubungan kirelasi berganda atau secara simultan dari kompetensi dan profesional auditor terhadap fraud mempunyai tingkat hubungan yang sangat kuat.

5. Berdasarkan hasil uji $\mathrm{f}$ secara simultan dapat dijelaskan berdasarkan nilai signifikan, nilai signifikan sebesar 0,00 yang mana di dalam teori pengambilan keputusan $0,00<$ 0,05 maka dari hasil tersebut dapat disimpulkan bahwa berdasarkan tarif signifikan $\mathrm{Ha}$ diterima Ho ditolak yang artinya terdapat pengaruh signifikan secara simultan pengujian-pengujian kompetensi dan profesional auditor terhadap fraud di PT.Mustika Ratu Tbk. Dari hasil output menghasilkan $\mathrm{f}$ hitung sebesar 47,251 yang mana di dalam teori pengambilan keputusan fhitung 47,251 > 3,59 maka dari hasil tersebut dapat disimpulkan bahwa berdasarkan nilai $f$ hitung dan $\mathrm{f}$ tabel Ha diterima dan Ha ditolak yang artinya terdapat pengaruh signifikan secara simultan penguji kompetensi dan profesional auditor terhadap fraud.

Hasil penelitian ini menghasilkan kesimpulan yang berada dengan penelitian sebelumnya yang di lakukan oleh (Karamoy, 2019) dimana penelitiannya berkesimpulan bahwa secara simultan ketiga variabel berpengaruh positif dan memiliki pengaruh sangat baik atau baik terhadap penerapan prinsip - prinsip tata Kelola yang baik.

\section{Kesimpulan}

1. Berdasarkan hasil pengujian yang telah dilakukan secara parsial terdapat pengaruh yang signifikan secara simultan antara Kompetensi terhadap Fraud di PT. Mustika Ratu TBK.

2. Berdasarkan hasil pengujian yang telah dilakukan secara parsial terdapat pengaruh yang signifikan secara simultan antara Profesional Auditor terhadap Fraud di PT. Mustika Ratu Tbk.

3. Berdasarkan hasil pengujian yang telah dilakukan secara parsial terdapat pengaruh yang signifikan secara simultan antara Kompetensi dan Profesional Auditor terhadap Fraud di PT. Mustika Ratu Tbk.

\section{Saran}

Berdasarkan peneliti selanjutnya dapat mengembangkan penelitian ini untuk dapat dijadikan sebagai bahan pengalaman dan pengetahuan, tanpa melupakan unsur keahliannya. Bagi peneliti selanjutnya, disarankan untuk menambah variabel independen untuk mengetahui faktor - faktor lain yang dapat mempengaruhi variabel dependen.

\section{DAFTAR PUSTAKA}

Agoes, S. (2017). Auditing. Salemba Empat.

Arum Ardianingsih. (2018). Audit Laporan Keuangan. Bumi Aksara.

Elfarini. (2010). Pengaruh kompetensi dan kualitas independensi auditor terhadap kualitas audit.

Karamoy. (2019). Pengaruh Peran Auditor Internal Terhadap Upaya Pencegahan dan Pendeteksian Kecuranagan: studi kasus di PT Sumber Pangan Gisindo.

Karyono. (2016). Forensik Fraud. Andi.

Matondang. (2010). Pengaruh Pengalaman Audit, Independensi, dan keahlian Profesional 
terhadap pencegahan dan pendeteksian kecurangan penyajian laporan keuangan: studi empiris Pada Kantor Akuntan Publik di DKI Jakarta.

Mulyadi. (2016). Auditing. Salemba Empat.

Nugrahini, P. (2015). Pengaruh kompetensi dan profsionalisme auditor internal terhadap kulitas audit.

Rai, G. A. (2010). Audit Kinerja. Salemba Empat.

Sugiyono. (2017). Metode Penelitian, Kuantitatif dan Kualitatif. Alfabeta.

Sugiyono. (2019). Metode Penelitian,Kuantitatif,Kualitatif dan R\&D. Alfabeta. 